\title{
Analysis on Economic Growth under Different Prevention and Control Measures of Covid-19 Pandemic
}

\author{
Wenyi Yang $1^{1^{*}}$ \\ ${ }^{1}$ Heilongjiang Province, China
}

\begin{abstract}
By the end of 2019 a novel kind of coronavirus which can infect human and trigger pneumonia is found in Wuhan City, China. The contagious virus rendered itself highly dangerous to attack human's immune system, and humans have to suspend their daily routine to derail the spread of this virus, named Covid-19 by WHO. It has upended the world, especially when people cannot go out to work and spend to create economic value in awe of contagion, leading to a nosedive taken by economic growth, and the healthy crisis transferred into an economic crisis. To control over the spread of virus and save economy, governments took many measures, but the effect varies from country to country. This article aims to find the liaison between the how fast and deep the governments are to fight against Covid-19 and how that relates to their recovery of economic growth, taking China and USA as typical examples, and draw the conclusion that the speed and depth the control taken over Covid-19 features a positive correlation with the recovery of economic growth.
\end{abstract}

\section{INTRODUCTION}

Since the Covid-19 was found in China and later haplessly diffused, raising panic and health economic problems around the globe, epidemiologists, economists and others who concern this question have been desperately finding measures to fight against it and bring life back to normal. To tackle and control the spread of Covid-19, medical scientists and researchers in related territories exerted all their strength. The economy under threat is worse. Economists are also keeping an eye on the economic recession caused by the health crisis.

There are economists like Joshua Gans who has published his book Economics in the age of covid-19. Since it is a global pandemic, every scientist and government intends to figure out how to contain it and salvage the economy from the recession or depression because of the health crisis. During the research and facts, given the infectivity of the virus, the countries which adopted fast and deep control over it seem to have the most effective result. Through this essay, the study is analyzing the control strategies and economic growth during this period, and helpful in terms of not only dealing with the crisis this time, but also other possible akin crisis in the future.

\section{ANALYSIS}

\section{A.The Patterns of Economic Growth Before and Under the Influence of Covid-19 Pandemic}

1) China: Though China had taken the first blunt of covid-19, it controlled the situation and economy took a bounce back from the nadir. Here are some charts that help to illustrate how the control and economy have changed.

It can be derived from the charts above that China had appeared an upward trajectory in economic growth before the rise of Covid-19, at a rate of over six percent on an annual basis, and its retail sales booming at a rate over eight on a monthly basis. After the first advent in its Hubei Province and spread of a novel coronavirus which later developed itself as a global pandemic, China adopted effective measures at a breakneck pace, mainly related to guideline of staying at home, lessening the contact between people to contain the diffusion of this virus. Due to the social distancing and staying at home guideline, most workers and consumers were not able to create value from both sides of supply and consumption, which dragged down the retail sales and further, GDP.

\footnotetext{
* Corresponding author: 1216088034@qq.com
} 


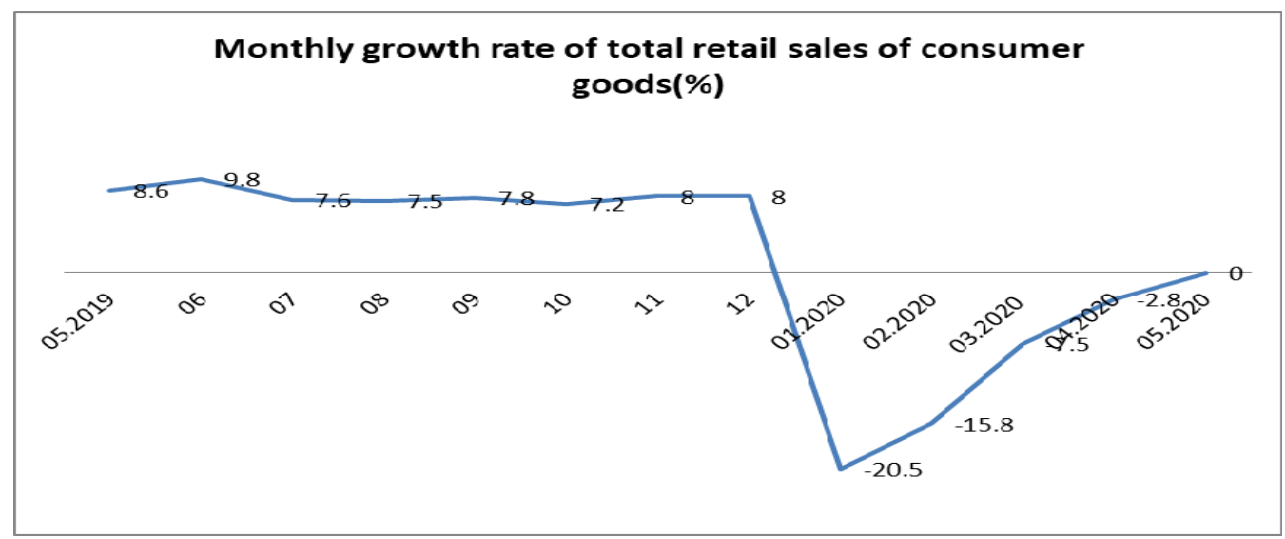

Figure 1. Monthly growth rate of total retail sales of consumer goods [1]

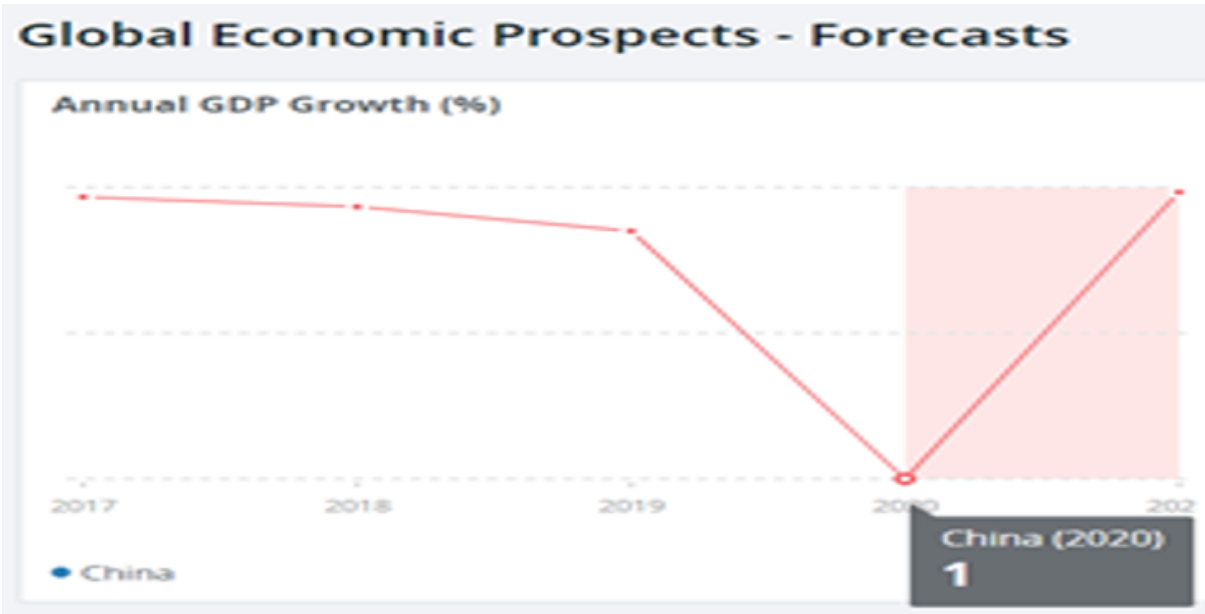

Figure 2. The current growth rate of china in 2020 and forecast in 2021(red)[2]

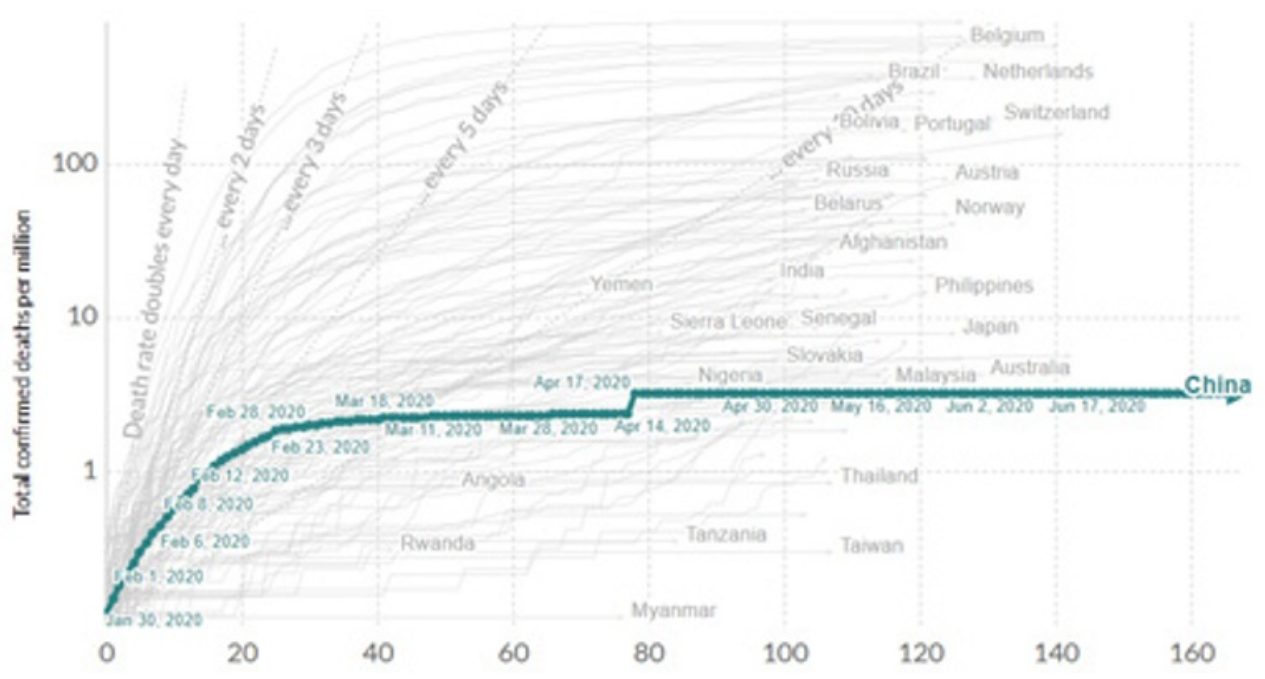

Figure 3. The speed with which Covid-19 caused deaths in China[3]

On the grounds that they cannot create as much as value to buttress their life as before the pandemic. For example, products cannot be produced and consumers cannot purchase goods, services as well as participating other economic activities. Nevertheless, thanks to the draconian and quick restriction of activities carried out by Chinese government such as wearing masks and social distancing, the economic growth of China is back by fits and starts. And from the last chart, the effective measures worked to flatten the curve before soaring as many other countries.

2) USA: From recent couples of months, it is derived that the United States has been the most hit country by covid-19 around the world. The death tolls or the infected are in dire straits, to say nothing ofthe economic growth. Here are some data that help demonstrate its predicament. 


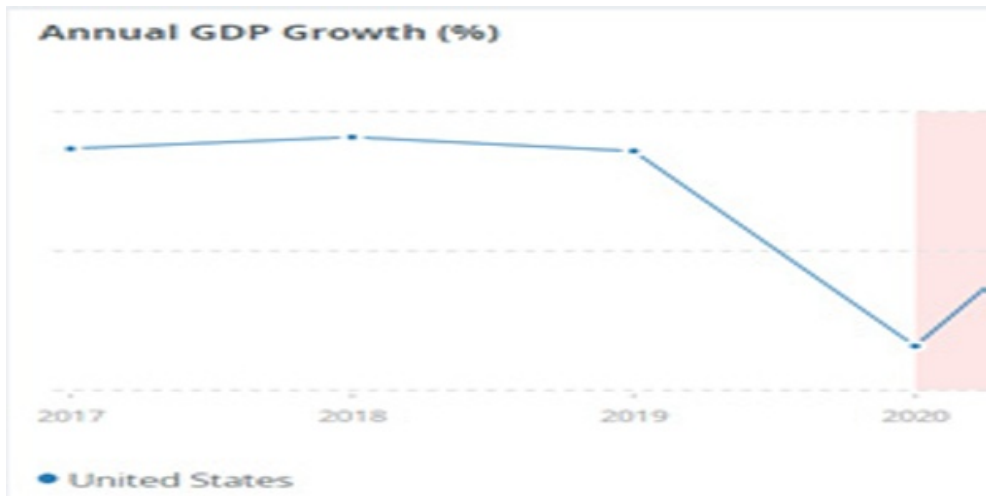

Figure 4. The economic growth of The United States[4]

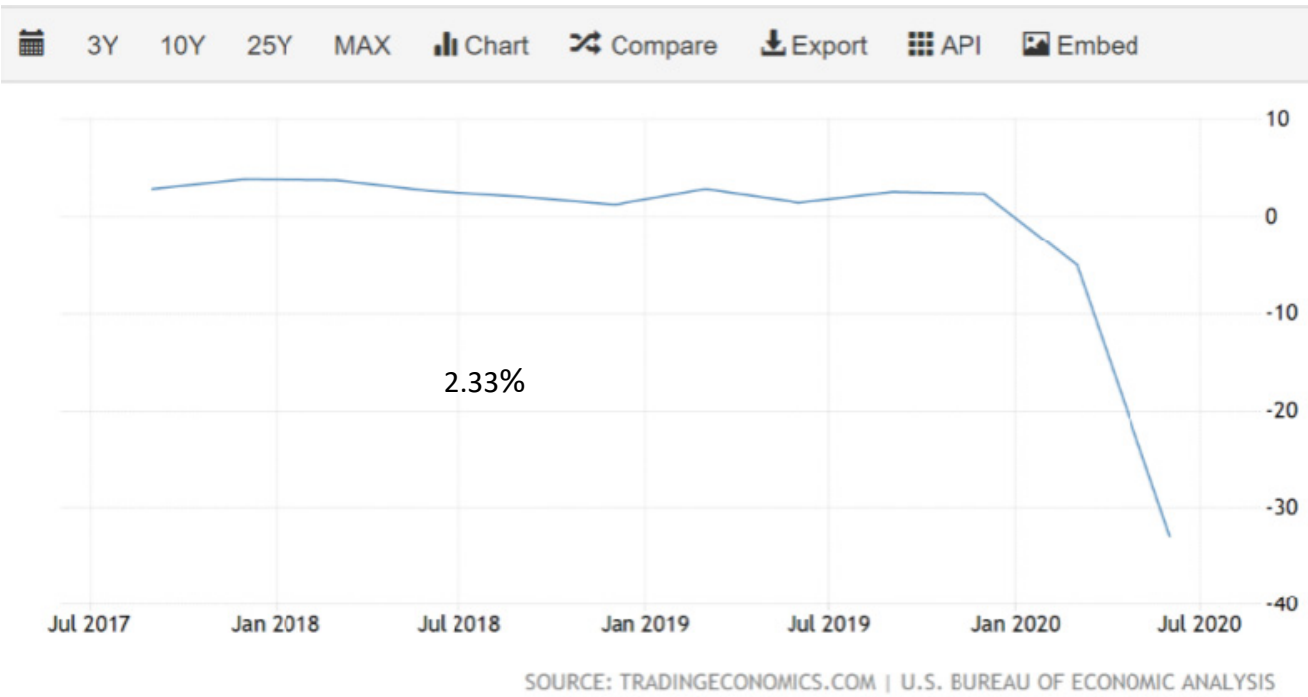

Figure 5. U.S. GDP Growth Rate from 2017-2020[5]

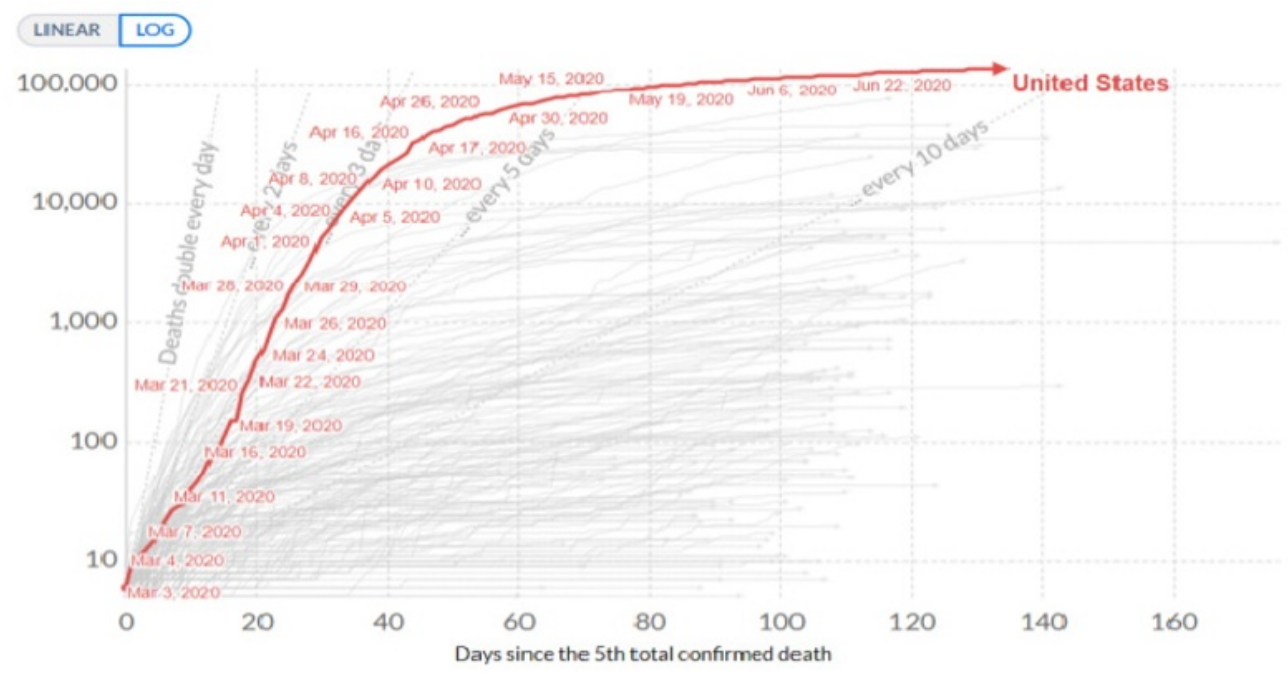

Figure 6. The speed with which Covid-19 caused deaths[6]

From the charts above, it can be seen a nosedive taken by the economy; the velocity of economic growth has been brought down to $-6.1 \%$ from $2.33 \%$ of last year, and continue deteriorating, after the economy had already taken a slight downside trajectory in 2019, accelerating to deteriorate the economy. As the pandemic went viral in whole America, some still fail to pay attention to the horror seriously, especially impacted by the leaders who should serve as the model for people to response to the pandemic properly, but preach trivial damage the virus will cause, thus slow to act against it. 
Albeit relative restrictions and guidelines were enforced, people seemed to inure themselves to tranquil and carefree life, not obeying those as seriously as in China. And the inconsistency of respective states rendered it less potent for central government to control the country to contain the spread, in a time when people need potent measures. Also, some may falsely utilized the ways they treated flu hundred years ago. Besides these conditions, the global supply chain which the United States relies on heavily was cut off due to social distancing, where exists many goods incorporating some raw materials indispensable for production were held back, leaving manufacturers and the mortals running short of necessities such as masks. Because people are not allowed to work outside, less producing, less consuming, fewer earnings, and rents unpaid, the economy is getting worse. And recently, reopening economy runs too fast under the undesirable conditions.

Even until today, the death toll caused by Covid-19 in United States top other countries and get severer, remaining the epicenter globally. Compared with China, the United States takes a lot more time, say, two or three months, than China to fight against Covid-19 at a higher cost of human and medical resources, even though it is not like China which is the first country haplessly hit by the novel coronavirus and should have already learnt experiences and lessons. A physical health issue leading to economic issue will also vitiate confidence and mental health of people, counted as other obstacles in terms of economic resurgence.

\section{B. Compare Methods Enforced}

To address the problem on both economy and public health, the methods have to come out from governments. The measures vary from countries to countries.

1) China: By and large, Chinese government responded quite quickly to the virus, though with some kind of delay, and the government carried out strict and potent measures with striking executive force. Here are some policy responses to contain the Covid-19 as follows.

a) Assistance to patients and the most infected areas: COVID-19 testing and related hospitalization are free, provided they remain available. The government pays for what insurance doesn't cover.In some cities, patients without severe symptoms can move to temporary shelters (converted from schools or fitness centers) and appointed hotels for quarantine and access to medical assistance on site. In Wuhan, about $20 \%$ of patients lived in designated shelters "Fangcang" with $24 / 7$ access to medical assistance.

While medical resources in Hubei Province, which includes Wuhan, were under tremendous stress, other regions in China "adopted" different cities in Hubei to send aid. Wuhan also built two temporary hospitals that accommodated one-third of the most severely affected patients during the peak of the outbreak. [7] b) Measures to Contain Spread: Social distancing is the commonest. First the Hubei Province where the epicenter Wuhan is was closed to focus on the most hit region since January 23rd, 2020. In fact the first confirmed case has been accepted at December 8th in 2019. Later the limit of transportation around the country and within cities was implemented. People were commanded to stay at home and had special workers hold the entrance of every community to prevent people from popping out too many times, usually more than three times. If they were going out for provisions, they must wear masks, or be forbidden to enter any public facilities. People began to go for the ride to stockpile sanitizers and masks.Schools and universities ceased any activities, turning to online education. Companies started to work from home.Limit nonessential travel abroad.Severely test anyone who comes to China from abroad, and in transport stations.

c) Measures in Communities to trace potential patients: Every citizen needs to log in a system that records their whereabouts within a certain period of time starting from the report of first confirmed case. The way for the system to record information of citizens is the use of OR code, printed on paper and pressed on doors of every store and public places, where everyone who wants to enter needs to scan the OR code and their footprints will be kept in the system. If anyone is confirmed positive for coronavirus, the stores he went to will be announced through media, and people who were there simultaneously with the patient will be quarantined as well. And school closed; companies ceased to work in the building.

Given the characteristic of Chinese government, policies are able to be implemented forcefully and effectively by central order, which may be dismissed as the violation of privacy as for some policies. And government took urgent measures to Hubei Province and other provinces later once they realized the severity of the novel coronavirus. The centralized power of Chinese government packed a punch in time when it comes to requirement of imperative measures to contain the spread of Covid-19. Until July, people in China have been able to live a roughly normal life without social distancing barring most schools and universities. The pandemic in China had been under control to a great extent in comparison with most countries.

2) USA: On March 15th, CDC urged that all gatherings of 50 or more people be canceled or postponed for the next eight weeks, two months later after the first confirmed case claimed in United States of America. The next day, the White House advised the public to avoid groups of more than 10 people.

As for the states: When Covid-19 cases reached 178 in New Jersey, Gov. Phil Murphy ordered a voluntary statewide curfew from 8 p.m. to 5 a.m. to keep people at home. On the same day, New Jersey joined with New York and Connecticut to keep casinos, gyms and movie theaters closed until further notice. Restaurants in numerous states started closing restaurant dining rooms, with only take-out or delivery offered. Every state began to carry out their own containment policy. 
Travel ban by federal government. [8]Several applications were invented to track the patients in people's communities. Send out PPE (Personal Protective Equipment) to workers in necessary territories.

Now it is known that America is facing the resurgence of Covid-19. Albeit there are many guidelines and measures, it still falls behind as to containing the virus. WHO has announced it is a pandemic, but from my perspective, Americans seemed to viewed the pandemic less crippling than Chinese, which is also one of the reasons why the Covid-19 cases appears to go through the roof. And also, the inequity among races and areas is also one of the reasons that the pandemic appears in direr straits longer than other countries, which can be proved by data: Black and Hispanic Americans are at the highest risk of infected by Covid-19, because they are left with hamstrung medical resources.

Compared with free testing and free treatment in China, the testing found itself very expensive for average Americans to say nothing of the fee if they are infected. Thus many people may choose to hide their situations.

Besides, Americans seemed to disbelieve the possibility of second wave or ignore deliberately the situation, or sunk into mental chaos, which can be seen from the internet that many comments emotionally refuted the news that reported undesirable facts about Covid-19.

\section{America's coronavirus cases are surging}

Daily new coronavirus cases, based on a seven-day moving average

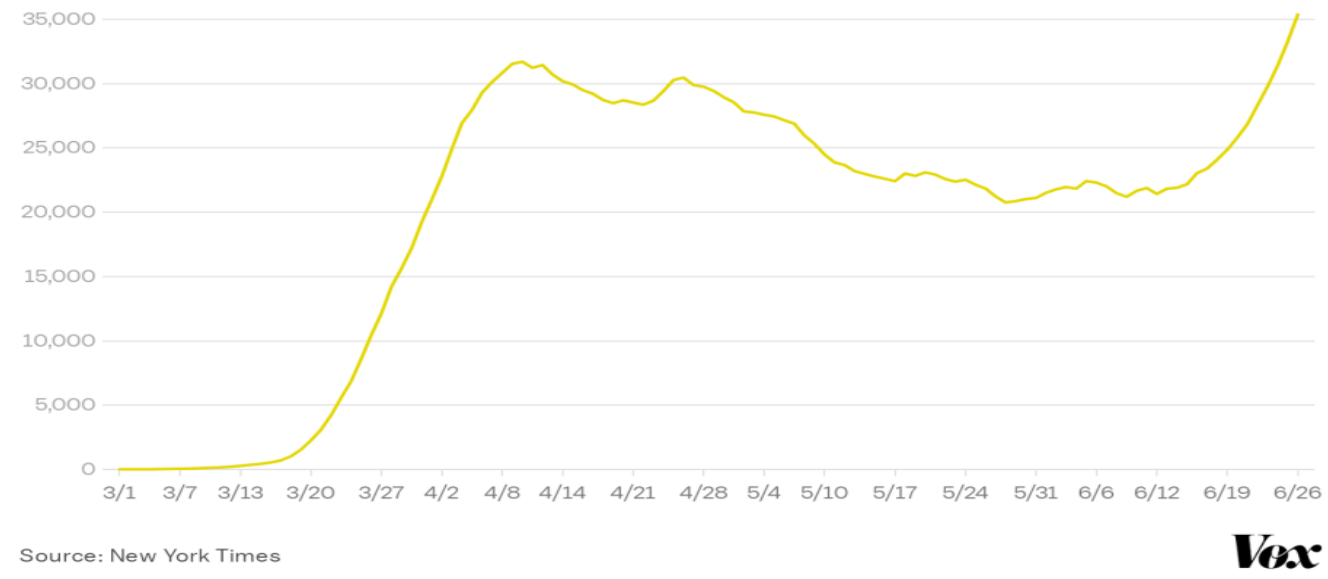

Figure 7. Surging pattern of Covid-19 in America [9]

\section{Correlation Between the Control Measures Taken by Governments and Economic Growth Guring Covid-19 Pandemic}

If the companies which count a lion's share in market are not bailed out in time, they may go bankrupt and get crashed, and the influence on the economy would be substantial, for example, soaring unemployment rate. If people cannot work and get paid to pay for their bills, the confidence and stability of the society will likely be trimmed. Thus, the governments should target and solve the problem as quickly as possible, and make really effective controls. Albeit herd immunity can be reached when around $60 \%$ of people are infected, it is unfeasible because the hospitals will be busted and leave more patients to die and cause panic in the society, demolishing economy.

1) China: The draconian measures controlled the spread of the Covid-19 from current perspective. From those aforementioned measures, Chinese government locked down the Hubei Province very quickly and began to chase everyone who arrived or passed there before, and even those who have family members or close friends who went there. The deep and quick responses to the coronavirus have effectively held back it, but government still stays agile and vigilant, which really helped afterwards. Even though a probable sign of second wave, the chopping board for slicing salmon detected positive for coronavirus in suburb Beijing, posed a threat, the government was able to trace the spread route, detect every likely case, and put every individual positive for Covid-19 in hospital.

Clearly, the speedy and strict control over Covid-19 keeps China a relatively stable life. With the control strategies introduced above, now the economy has been reopened, and that Chinese are living a normal life in a great proximity to what they used to, with requirement of wearing masks and closure of schools, as well as some territories still working from home. And custom officials are still pulling out all the stops to hold back Covid-19 outside the boundary of China. In figure 1, it can be seen that the retail sales are elevating by degrees, though lower than pre-covid time.

2) USA: At first, a cavalier atmosphere about the danger of Covid-19 mantled the United States of America. Americans do not take masks and federal government failed to take quick actions against virus. The governors of many states can be seen from television that whined about the insufficient aid from federal government. PPE 
and ventilators are always short to save people, and the characteristics of American government make it less potent and deep to reinforce the rules to tighten the spread.

As a result, when citizens in America face the increasingly conspicuous fact that America has been the most hit country in the world, they commenced to lose their equilibrium. Besides, the economic growth there is boosted primarily by market instead of government like China, which enfeebled itself under such conditions where central power is especially entailed. And the tracing-virus applications are owned by some individual companies instead of government, making the tracing effective in a much narrower range than a whole country.

Though it is urgent to reopen economy, the resurgence of Covid-19 cases are backtracking the efforts. It is to be reckoned that the concern to Covid-19 has been downsized by President Donald Trump, which led to the dire situation where economy has to shut down once again and the destabilization of society raises turbulence on the recovery economy. Considering China and most other countries in the world has made considerable progress in stabilizing the spread and severity of Covid-19, the United States is slow to make impressive progress, due to being sluggish to react against it, and the fact that the central government is slow to push the strategies of containment deeper and strictly. The economic growth now is driven by stay-at-home stocks such as technology and investors' confidence of upcoming vaccines.

\section{ConClusion}

The article analyzed how the speed and depth with which countries implemented control over Covid-19 affect economic growth. From what is illustrated above, the quicker and deeper measures are taken, the better and quicker the economic growth recover.

Given the fact that the covid-19 is a super-contagious virus, the speed of control is overriding, helping to stabilize the situation before it gets tricky to handle. Furthermore, the depth is indispensable. Tracking the infected and their families and people they contact with is helpful to cut the contagious chain from patient zero, finding out potential patients as many as possible. China has very draconian and fast strategies and control over every aspect of spread of covid-19 and still keeps vigilant about the spread from abroad till now, and the results prove that the speed and depth of control strategies is both useful and effective, with the control group, the United States.

It also shows the importance of leadership in the crisis, helping society and economy weather the storm. From the examples, Chinese government is powerful in terms of organizing the fight against Covid-19 while its counterpart of the United States underestimated the virus thus slow to set control in motion and not so ideal to tackle the situation within its own boundary. Besides, the issue of health care system and how it extends its favors to citizens is worthwhile to look into as to the effectiveness of controlling covid-19 and thereby rehabilitating economy.

\section{ACKNOWLEDGEMENT}

I would like to extend my gratitude to all those who helped me and offered me practical, cordial and selfless support in my writing this essay, my professor Paul-Armstrong Taylor, TA and instructor Olivia Sun who helped me address my problems about writing, and instructed me. I couldn't accomplish this without their help.

\section{REFERENCES}

[1] Data Centre of Oriental Fortune.2020.3

[2] World Bank. https://data.worldbank.org/country/china?view=chart 2020.7

[3] Our World in Data. https://data.worldbank.org/country/china?view= chart. 2020.7.15

[4] World Bank. https://data.worldbank.org/country/united-states?view= chart. 2020.7

[5] Trading Economics. https://tradingeconomics.com/united-states/gdp- growth. 2020.7

[6] Our World in Data. https://ourworldindata.org/covid-deaths. 2020. 7.15

[7] China's Policy Response to Covid-19, CBRE 202003.27

[8] America is racing to contain the coronavirus spread. Here's how the pandemic changed the country this week, $\mathrm{CNN}$, Nichole Chave, 2020.3.21

[9] Vox.https://www.vox.com/2020/6/27/21302495coronavirus-pande mic-second-wave-us-america,2020.6.27 